\title{
A cointegration analysis of crude palm oil price in Thailand
}

\author{
Patchaya Songsiengchai ${ }^{1, *}$, Shaufique F. Sidique ${ }^{2,3}$, Marcel Djama ${ }^{3,4}$, and W.N.W. Azman- \\ Saini $^{2}$ \\ ${ }^{1}$ Faculty of Management Science, Nakhon Ratchasima Rajabhat University, 30000 Nakhon \\ Ratchasima, Thailand \\ ${ }^{2}$ Faculty of Economics and Management, Universiti Putra Malaysia, 43400 UPM Serdang, Malaysia \\ ${ }^{3}$ Institute of Agricultural and Food Policy Studies, Universiti Putra Malaysia, 43400 UPM Serdang, \\ Malaysia \\ ${ }^{4}$ Cirad, UMR Moisa - Marchés, Organisations, Institutions et Stratégies d'Acteurs, 34398 Montpellier \\ Cedex 5, France
}

\begin{abstract}
Reliazing the pass-through effects of global commodity prices on domestic prices, this study develops a vector error correction model (VECM) to test for the determinants and direction of causality between global prices and crude palm oil (CPO) price in Thailand. Malaysian crude palm oil, world soybean oil and world crude oil prices were investigated as factors affecting the Thai CPO price. Using the Johansen cointegration test, the result unveils a presence of long-run relationship among the determinants. This long-run relationship, proposes that CPO price flows in Thailand are positively influenced by the Malaysian CPO price and the error correction term suggests that approximately 35 percent of total disequilibrium in Thai CPO price was corrected in the following month. Moreover, the findings show Granger causality from each of the Malaysian CPO price and the world soybean oil price for the Thai CPO price. Information flow regarding the price movements of the Malaysian CPO and soybean oil affect the Thai CPO price and vice-versa. Whereas, the evidence for a causal relationship that runs from the world crude oil price to the Thai CPO price is found, but not in reverse.
\end{abstract}

\section{Background}

Palm oil is an essential product that is regularly consumed in households and is used as a raw material in industrial production for numerous products. Many countries are concerned about the price of palm oil used in industries and commercials because if the price of palm oil rapidly increased, it will cause inevitable rising in the living standards and lifestyle [1-3]. As the global prices of food and commodities are now widely believed to be co-integrated [4], there could be pass-through; at least partly, between the global prices and final consumer prices. When there is a rise in global prices, it eventually affects the domestic product prices in one way or another [5]. Domestic policies that aim to protect the

\footnotetext{
* Corresponding author: patchaya.s@nrru.ac.th
} 
domestic prices may not be able to prevent the effects of global price changes in the longrun [6].

In the case of Thailand, the production volumes of Thailand may be small compared to that of leading countries, Indonesia and Malaysia. It can sufficiently produce and supply palm oil for the domestic market and export the surplus to its neighbouring countries [7]. The trend of palm oil supply and demand in Thailand is continuously increasing. Several projects were supported by the government to expand oil palm cultivation areas [8]. Its demand increased because the palm oil price is affordable compared to other edible oils and is used as an input to other industries and biodiesel production. High demand for palm oil and greater yield at a lower cost in the production of oil palm makes palm oil industry worthy of attention. Therefore, to create a stable and sustainable industry for the long-run, the effects of global price changes on palm oil price are essential to study. This study employed a cointegration analysis of price transmission from global prices to crude palm oil price in Thailand. An excellent understanding of the price mechanism and its determinants will encourage and support the productive production [9].

There is numerous literature on the effect of crude oil price pass-through to the domestic economy and agricultural commodity prices. Applanaidu et al. [10] showed the prices of biofuel feedstock, such as palm oil, soybean oil, rapeseed oil and maize are inevitably following crude oil prices. Jiménez-Rodríguez [11] showed the evidence of oil price shock on inflation and domestic products. Brown and Yücel [12-13] demonstrated that increases in oil price is reflected in reducing output efficiency as well as the rising cost of production. Lardic and Mignon [14] presented the consumption and investment effects after oil price shock. Also, Balach et al. [15] revealed the impact of oil price increase in soybean oil price.

Contrary to the above studies, Yu et al. [16] stated that the shocks in crude oil price have no significant effect on the variation of the edible oil prices. Chuangchid et al. [17] showed fairly weak dependence between crude oil and palm oil prices. Additionally, Hameed and Arshad [19] provided evidence of the strong relationship between petroleum and palm oil prices in the long-run but not in the short-run. These contradictory findings of the previous empirical studies raise a need for further studies to clarify the conceptions.

Moreover, there are a number of evidence from previous studies showing the relationship between crude palm oil (CPO) and soybean oil prices, and the impact of Malaysian CPO price to the Thai CPO price. According to Abdullah and Wahid [20] soybean oil price is a common factor affecting CPO price, which has been widely accepted in previous studies and concludes that they are two close substitute commodities. Also, Rungreunganun et al. [21] found that besides soybean oil price, Malaysian CPO price affects the Thai CPO price. Hence to study the price mechanism of crude palm oil in Thailand, this study used world crude oil, Malaysian CPO, and world soybean oil prices as the determinants affecting Thai CPO price.

The remaining part of the paper is organized as follows: Section 2 presents the methodology used in the study, Section 3 illustrates data and empirical model, Section 4 shows empirical results, Section 5 discusses the findings, and Section 6 concludes the paper and suggests policy implications.

\section{Methodology}

\subsection{Cointegration and vector error correction model}

According to Engle and Granger [19], two or more series of non-stationary data may exist as a stationary linear combination if they are cointegrated. Such that, the linear combination can be written as: 


$$
\mu_{t}=y_{t}-\alpha_{0}-\beta_{i} x_{i}
$$

where $\mu_{t}$ is stationary, and $y_{t}$ and $x_{i}$ are set of non-stationary data. This combination also represents the relation of long-run equilibrium among the variables.

To estimate the long-run relationship of the above equation, Hoffman and Rasche [23] suggested using a vector error correction model (VECM) that offers a long-run relation and provides efficient coefficient estimates. The estimating procedure of VECM model consists of four steps. First, testing for unit root tests. This step is a requirement before processing to cointegration analysis, to check whether the data series are stationary and examine the integration properties of the data. The widely used Augmented Dickey-Fuller (ADF) and Phillips-Perron (PP) unit root tests are applied in this study. Next, identify and estimate a vector autoregressive (VAR) model of the integrated series. Then, selecting an appropriate lag order of a VAR model using model selection criteria such as Sequential Likelihood Ratio (LR), Final Prediction Error (FPE), Akaike Information Criterion (AIC), Schwarz Information Criterion (SIC) and Hannan-Quinn Criterion (HQC). Finally, employing Johansen [24] cointegration test and Johansen and Juselius [25] maximum likelihood for indicating the rank of cointegration equation and estimating a VECM model. The VECM model can be written as:

$$
\Delta y_{t}=\Pi y_{t-1}+\sum_{i=1}^{k-1} \Gamma_{i} \Delta y_{t-i}+\mu+\epsilon_{t}
$$

where $y_{t}$ is a $(n \times 1)$ vector of the $n$ variables. $\Delta$ is a first difference operator. $\Pi$ is a $(n \times n)$ coefficient matrix. $\Gamma$ denotes a $(n \times(k-1))$ matrix of short-run coefficients, $\epsilon_{t}$ represents a $(n$ $\mathrm{x} 1)$ vector of white noise disturbances. The reduced rank of matrix $\Pi(0<r<n)$ can be separated into a $(n \times r)$ matrix of coefficients $\alpha$ and a $(n \times r)$ matrix of cointegrating vectors $\beta$. Such that, the reduced rank of matrix $\Pi$ can be written as $\Pi=\alpha \beta^{\prime}$ where $\alpha$ represents the importance of the cointegration relationships in the individual equations of the speed adjustment to disequilibrium and $\beta$ indicates the long-run relationship.

\subsection{Causality test}

To estimate the short-run deviation from their long-run relationship, Granger [26] suggested an error correction term in the stationary model as:

$$
\Delta y_{t}=\alpha_{1}+\gamma\left(y_{t-1}-\beta x_{t-1}\right)+\sum_{i=1}^{k} \delta_{i} \Delta y_{t-i}+\sum_{i=1}^{m} \eta_{i} \Delta x_{t-i}+\epsilon_{i t}
$$

where $\left(y_{t-1}-\beta x_{t-1}\right)$ is the error correction term $\left(E C T_{t-1}\right) \cdot x_{t}$ is said not to Granger cause $y_{t}$ if $x_{t}$ cannot help to predict the future of $y_{t}$.

\section{Data and empirical model}

An econometric approach has been adopted in this paper to examine the determinants of $\mathrm{CPO}$ price in Thailand. The model as the following will be estimated:

$$
\mathrm{TCPO}_{t}=f\left(\mathrm{MCPO}_{t}, \mathrm{WSB}_{t}, \mathrm{WCO}_{t}\right)
$$

where TCPO refers to the crude palm oil price in Thailand, MCPO is Malaysian crude palm oil price, WSB is the world soybean oil price and WCO is world crude oil price. All data are compiled from the World Bank database, except Thai crude palm oil price is collected from the Department of Internal Trade, Ministry of Commerce, Thailand. The unit of crude palm oil prices and soybean oil price series was in USD/ton, while the world crude oil price 
series was in the unit of USD/barrel. The monthly data over 1996 to 2015 period, total 237 observations were obtained to the study.

\section{Results}

Table 1 illustrates the summary statistics for the Thai CPO price and its determinants. During the period of 1996 to 2015, the average price of world soybean oil was the highest at $689.67 \mathrm{USD} /$ ton, with the maximum of $1,414.42 \mathrm{USD} /$ ton and the minimum of 321.43 USD/ton. The average of Thai CPO price was the second highest price series in the study, but is quite volatile with a standard deviation of 283.54, a maximum of $1,903.19$ and a minimum of $192.54 \mathrm{USD} /$ ton. The difference between the average value of Thai CPO and Malaysian CPO is around $60 \mathrm{USD} /$ ton. Except Thai CPO price, all price series are positively skewed, with kurtosis coefficients less than three or thin tails. These are confirmed by the result of Jarque-Bera test statistics that all price series data are not a normal distribution. Therefore all price series data are transformed into natural logarithm.

Table 1. Summary statistics of Thai CPO price and its determinants

\begin{tabular}{|c|r|r|r|r|}
\hline & \multicolumn{1}{|c|}{ TCPO } & \multicolumn{1}{c|}{ MCPO } & \multicolumn{1}{c|}{ WSB } & \multicolumn{1}{c|}{ WCO } \\
\hline Mean & 640.11 & 580.41 & 689.67 & 56.57 \\
\hline Median & 581.75 & 509.47 & 586.78 & 50.18 \\
\hline Maximum & $1,903.19$ & $1,248.55$ & $1,414.42$ & 132.72 \\
\hline Minimum & 192.54 & 185.07 & 321.43 & 9.82 \\
\hline Std. Dev. & 283.54 & 250.67 & 284.35 & 35.43 \\
\hline Skewness & 1.00 & 0.68 & 0.72 & 0.46 \\
\hline Kurtosis & 4.83 & 2.66 & 2.44 & 1.83 \\
\hline Jarque-Bera & $72.61 * * *$ & $19.41 * * *$ & $23.85^{* * *}$ & $21.94 * * *$ \\
\hline
\end{tabular}

Table 2 presents unit root test results at a level and first difference. Augmented DickeyFuller (ADF) and Phillips-Perron (PP) unit root tests were conducted for stationarity test. Both unit root tests showed that at the level all the series data are non-stationary ( $p$-value $>$ $0.05)$, implying that all the variables are not $I(0)$. For the first difference, the unit root tests were also conducted. The computed values of statistics are all significant at one percent level ( $p$-value $<0.01)$, indicating the rejection of the existence of a unit root for each price series in their first difference. Thus, all the variables are integrated of order 1 or $I(1)$.

Table 2. ADF and PP unit root tests results

\begin{tabular}{|c|c|c|c|c|c|c|c|c|}
\hline \multirow{3}{*}{ Variable } & \multicolumn{4}{|c|}{ ADF Test } & \multicolumn{4}{|c|}{ PP Test } \\
\hline & \multicolumn{2}{|c|}{ Level } & \multicolumn{2}{|c|}{ First Difference } & \multicolumn{2}{|c|}{ Level } & \multicolumn{2}{|c|}{ First Difference } \\
\hline & $t$-value & $p$-value & $t$-value & $p$-value & $t$-value & $p$-value & $t$-value & $p$-value \\
\hline \multicolumn{9}{|l|}{ Intercept: } \\
\hline LTCPO & -1.991 & 0.291 & -11.206 & 0.000 & -2.086 & 0.251 & -11.430 & 0.000 \\
\hline LMCPO & -1.828 & 0.366 & -6.262 & 0.000 & -1.728 & 0.416 & -10.499 & 0.000 \\
\hline LWSB & -1.578 & 0.492 & -10.601 & 0.000 & -1.518 & 0.523 & -10.624 & 0.000 \\
\hline LWCO & -1.564 & 0.499 & -12.487 & 0.000 & -1.548 & 0.508 & -12.481 & 0.000 \\
\hline \multicolumn{9}{|c|}{ Intercept and trend: } \\
\hline LTCPO & -3.261 & 0.076 & -11.177 & 0.000 & -2.878 & 0.172 & -11.396 & 0.000 \\
\hline LMCPO & -2.707 & 0.235 & -6.250 & 0.000 & -2.082 & 0.553 & -10.477 & 0.000 \\
\hline LWSB & -1.927 & 0.637 & -10.587 & 0.000 & -1.856 & 0.674 & -10.612 & 0.000 \\
\hline LWCO & -1.804 & 0.700 & -12.511 & 0.000 & -1.708 & 0.745 & -12.506 & 0.000 \\
\hline
\end{tabular}

Estimation results of the VAR model for determining an optimum lag order is given in Table 3. The all criteria Sequential Likelihood Ratio (LR), Final Prediction Error (FPE) and Akaike Information Criterion (AIC) called for three lags, except the Schwarz Information 
Criterion (SC) and Hannan-Quinn information criterion (HQ) that called for two lags. Therefore, this study decided to choose lags three as an optimum lag in the model.

Table 3. VAR lag order selection criteria

\begin{tabular}{|c|c|c|c|c|c|c|}
\hline Lag & LogL & LR & FPE & AIC & SIC & HQ \\
\hline 0 & 68.043 & NA & $6.72 \mathrm{e}-06$ & -0.5593 & -0.4994 & -0.5351 \\
\hline 1 & 1204.488 & 2223.263 & $3.78 \mathrm{e}-10$ & -10.3449 & -10.0450 & -10.2239 \\
\hline 2 & 1251.417 & 90.169 & $2.88 \mathrm{e}-10$ & -10.6150 & $-10.0752^{*}$ & $-10.3972^{*}$ \\
\hline 3 & 1273.041 & $40.793^{*}$ & $2.75 \mathrm{e}-10^{*}$ & $-10.6641^{*}$ & -9.8844 & -10.3496 \\
\hline
\end{tabular}

Note: $*$ denotes significance at $5 \%$ level

As all variables in the model are integrated of order one, the Johansen cointegration test is selected to identify long-run relationships The results are provided in Table 4. Assuming there is no deterministic trend in data and no intercept or trend in the cointegration equation, the results of both Trace statistics and Max-Eigen Statistics suggest there are two cointegrating equations at the $5 \%$ significance level. These indicate that there are long-run relationships between Thai crude palm oil price and its determinants. The long run relationships estimation are showed in equation (5).

Table 4. Johansen cointegration test

\begin{tabular}{|c|c|c|c|c|c|c|c|}
\hline $\mathbf{H}_{\mathbf{0}}: \mathbf{r a n k}=\mathbf{r}$ & $\begin{array}{c}\text { Eigen } \\
\text { value }\end{array}$ & $\begin{array}{c}\text { Trace } \\
\text { Statistic }\end{array}$ & $\begin{array}{c}\mathbf{0 . 0 5} \\
\text { Critical } \\
\text { Value }\end{array}$ & $\boldsymbol{p}$-value & $\begin{array}{c}\text { Max-Eigen } \\
\text { Statistic }\end{array}$ & $\begin{array}{c}\mathbf{0 . 0 5} \\
\text { Critical } \\
\text { Value }\end{array}$ & $\boldsymbol{p}$-value \\
\hline $\mathrm{r}=0^{*}$ & 0.162 & 72.651 & 47.856 & 0.000 & 41.031 & 27.584 & 0.001 \\
\hline $\mathrm{r} \leq 1^{*}$ & 0.093 & 31.620 & 29.797 & 0.031 & 22.797 & 21.132 & 0.029 \\
\hline $\mathrm{r} \leq 2$ & 0.029 & 8.823 & 15.495 & 0.382 & 6.807 & 14.265 & 0.512 \\
\hline $\mathrm{r} \leq 3$ & 0.009 & 2.016 & 3.842 & 0.156 & 2.016 & 3.842 & 0.156 \\
\hline
\end{tabular}

Note: $*$ denotes rejection of the hypothesis at the $5 \%$ level.

$$
\begin{aligned}
& L_{T C P O}=1.1440 \mathrm{LMCPO}_{t}-0.3055 \mathrm{LWSB}_{t}+0.0808 \mathrm{LWCO}_{t} \\
& \begin{array}{lll}
\text { (7.4712) } \quad(-1.4777) \quad(1.7749)
\end{array}
\end{aligned}
$$

Note: Numbers in parentheses are t-statistics.

The above equation indicates that in the long run Malaysian CPO price and world crude oil price are positively impacting Thai CPO price, while the world soybean oil price negatively induces it. The estimated elasticity of the determinants of Thai CPO price is $1.1440,0.0808$ and -0.3055 , respectively. However, only the Malaysian CPO price seems to be significant factor.

Since the result of Johansen showed cointegrating vectors are existing, we estimate the vector error correction model to indicate the speed of adjustment to long-run changes. The VECM model is determined by the maximum likelihood method, and the optimum lag is decided by the AIC criterion to be 3 . The robustness of the VECM model is evaluated by using the Portmanteau autocorrelation test and the autocorrelation LM test. The Portmanteau autocorrelation test shows that the Ljung-Box $Q$-statistics and Adjusted $Q$ statistics are equal to 152.6996 and 158.1062 , respectively. Therefore, we cannot reject the null hypothesis of no serial correlation up to lag 12. Moreover, the autocorrelation LM test presents the LM statistics of 16.0111 at $12^{\text {th }}$ lags which the statistics cannot reject the null of no serial correlation indicating that there is no serial correlation in the model up to lag 12. Hence, we can continue to interpret the result of VECM model.

The result in Table 5 revealed the error correction term (ECT) in each equation, however, this study only focuses on the Thai CPO equation. The ECT in the Thai CPO price equation showed a coefficient of -0.3492 and significant at the $1 \%$ level. This implies 
that the speed of adjustment towards the equilibrium takes place by $34.92 \%$ per month. In other words, if there is a shock occurred in the Malaysian CPO market, a unit increases in Malaysian CPO price that increases 1.14 units in Thai CPO price is corrected by a factor $34.92 \%$ per period. It will revert to its long-run equilibrium within four months of correcting by $80 \%$ of the deviation and will take almost seven months of adjusting $95 \%$ of the deviation. This result confirms the effect of global prices pass-through to the domestic price and clearly demonstates how important could be the effect of shocks to crude oil and Malaysian CPO prices on the Thai CPO price.

Table 5. Error correction model

\begin{tabular}{|c|c|c|c|c|}
\hline Error Correction: & D(LTHCPO) & D(LMYCPO) & D(LWSB) & D(LWCO) \\
\hline \multirow{3}{*}{ Cointegration equation } & $-0.3492^{* * *}$ & $-0.1407^{* * *}$ & $-0.0796^{* *}$ & $0.1397^{* *}$ \\
\cline { 2 - 5 } & $(0.0598)$ & $(0.0434)$ & $(0.0338)$ & $(0.0579)$ \\
\cline { 2 - 5 } & {$[-5.8376]$} & {$[-3.2438]$} & {$[-2.3573]$} & {$[2.4150]$} \\
\hline
\end{tabular}

Note: $* *$ and $* * *$ denote significance at $5 \%$ and $1 \%$ levels, respectively. Numbers in parentheses are standard errors and numbers in brackets are t-statistics.

This paper also checked the robustness of the error correction model in Thai CPO price using the $Q$-statistic of the Ljung-Box statistic autocorrelation test and the autocorrelation LM test as well as the heteroskedasticity ARCH test. The diagnostic results are provided in Table 6. The results indicate that the single error correction model of Thai CPO price does not suffer from the serial correlation problem since the $Q$-statistics and the statistic of the Breusch-Godfrey Serial Correlation LM test cannot reject the null hypothesis of no serial correlation; meaning that the residuals in the model are not correlated with one another. Besides, the chi-square statistics of ARCH test for heteroskedasticity is not significant, implying that the residuals are homoskedasticity.

Table 6. Residuals diagnostics of the estimated error correction model

\begin{tabular}{|c|c|c|}
\hline \multirow{2}{*}{ Diagnostic tests } & \multicolumn{2}{|c|}{ Thai CPO price } \\
\cline { 2 - 3 } & Statistics-value & $P$-value \\
\hline$Q(4)$ & 1.6653 & 0.7970 \\
\hline$Q(8)$ & 5.9212 & 0.6560 \\
\hline LM(2) & 0.0425 & 0.9790 \\
\hline LM(4) & 6.3521 & 0.1743 \\
\hline ARCH(1) & 0.6075 & 0.4357 \\
\hline
\end{tabular}

Note: $Q(p)$ is the $Q$-statistics of standardized residuals at $p^{\text {th }}$ order that test for serial correlation. $\operatorname{LM}(k)$ is $\mathrm{LM}$ test for serial correlation up to $k^{\text {th }}$ order. $\mathrm{ARCH}(m)$ is autoregressive conditional heteroskedasticity test in $m$ lag order.

Table 7 reveals the results of Granger causality, showing the bidirectional causality between Thai CPO price and Malaysian CPO price, and world soybean oil price and Thai CPO price, but only a unidirectional causality running from world crude oil price to the Thai CPO price.

Table 7. Results of granger causality

\begin{tabular}{|c|c|c|c|c|}
\hline Variable & Chi-Square Test & df & $\boldsymbol{p}$-value & Causality \\
\hline $\mathrm{TCPO} \rightarrow \mathrm{MCPO}$ & 14.5388 & 3 & 0.0023 & Yes \\
\hline $\mathrm{MCPO} \rightarrow \mathrm{TCPO}$ & 8.8838 & 3 & 0.0309 & Yes \\
\hline $\mathrm{TCPO} \rightarrow \mathrm{WSB}$ & 7.3678 & 3 & 0.0611 & Yes \\
\hline $\mathrm{WSB} \rightarrow \mathrm{TCPO}$ & 6.4220 & 3 & 0.0928 & Yes \\
\hline $\mathrm{TCPO} \rightarrow \mathrm{WCO}$ & 0.2297 & 3 & 0.9727 & No \\
\hline $\mathrm{WCO} \rightarrow \mathrm{TCPO}$ & 7.9662 & 3 & 0.0467 & Yes \\
\hline
\end{tabular}




\section{Discussion}

The findings uncover that Thai CPO price is positively related to Malaysian CPO and world crude oil prices, while negatively related to world soybean oil price. These findings are consistent with Rungreunganun et al. [21] in the view that Malaysian CPO and soybean oil prices are the factors affecting Thai CPO price. Unfortunately, the sign of soybean oil price is found to be contrasted with the study. Furthermore, the results are in line with findings provided by Applanaidu et al. [10] that showed the positive relationship between crude oil and vegetable oils.

The causality analysis reveals that bidirectional causalities are running between the Malaysian CPO and world soybean oil prices to the Thai CPO price, while unidirectional causality is running from world crude oil price to the price of Thai CPO. These causality findings are similar to those obtained by Nazlioglu and Soytas [4] and Hameed and Arshad [19]. This is in contrast with $\mathrm{Yu}$ et al. [16] and Campiche et al. [27] that did not find any evidence of crude oil price shocks influence on edible oil prices, including palm oil. Yu et al. [16] suggested that if the prices of crude oil continue rising and edible oils become a growing source of biodiesel, the influence of crude oil price on edible oil prices would be raised.

\section{Conclusion}

This paper attempts to expose the determinants of crude palm oil price in Thailand from 1996 to 2015. The key determinants of the Thai CPO price that was focusing in this paper are Malaysian CPO price, world soybean oil price, and world crude oil price. The analysis unveils the significant positive relationship between Malaysian CPO and Thai CPO prices. Moreover, the finding for the dynamic relation reveals that approximately $34.92 \%$ of total disequilibrium in the long-run relation between Thai CPO price and its determinants is corrected each month. Further, Granger causality results indicate bidirectional causality between the prices of Malaysian CPO to the Thai CPO.

With this, it can be concluded that Malaysian CPO price is an impacting factor to CPO price in Thailand. A high level of Malaysian CPO price leads to a high level of Thai CPO price. Likewise, any shocks to Malaysian CPO price will affect on Thai CPO price in the same direction. Therefore, to maintain the welfare of domestic consumers and create sustainable industry, stabilization of the Thai CPO price and monitoring changes in global prices are necessity. These could be achived by setting daily price change ceilings and maintaining a balance of the domestic stock as well as providing alternative sources to supply when there is an excess of CPO. Because CPO is an intermediate material of various commodities, it would help to balance the prices of numerous products.

\section{References}

1. D. F. Larson, Policy Research Working Paper 1654, Washington DC, (1996).

2. A. Rifin, IAAE, Beijing, (August, 2009).

3. M. Harjanti, The Impact of Palm Oil Price Swings on Household Welfare: The Case of Indonesia, (2012).

4. S. Nazlioglu and Ugur Soytas, Oil price, agricultural commodity prices, and the dollar: A panel cointegration and causality analysis, Energy Economics, 34.4 (2012)

5. OAE. Thailand Foreign Agricultural Trade Statistics 2016 (2017). 
6. Office of Agricultural Economics Research. Strategic of Oil Palm Industry 2004-2029 (2004).

7. J. Tracey-White, Market Infrastructure Planning: A Guide for Decision Makers, (2015).

8. S. D. Applanaidu, F. M. Arshad, M. N. Shamsudin, Z. Yusop, ICBER, Sarawak, (March, 2010).

9. R. Jiménez-Rodríguez, Macroeconomic structure and oil price shocks at the industrial level, International Economic Journal, 25 (1), 173-189 (2011)

10. S. Rafiq, P. Sgro and N. Apergis, Asymmetric oil shocks and external balances of major oil exporting and importing countries. Energy Economics, 56, $42-50$ (2016)

11. S. P. A. Brown, M. K. Yücel, QREF, 42, 193-208, (2002).

12. S. Lardic, and V. Mignon, Oil prices and economic activity: An asymmetric cointegration approach. Energy Economics, 30(3), 847-855 (2008)

13. R. Balach, B.T. Matemilola, L. Chin, A. Baloch, EEL, 15, 15-24, (2016).

14. T.H. Yu, D. A. Bessler, S. Fuller, AAEA Annual Meeting, California, (July, 2006).

15. K. Chuangchid, A. Wiboonpongse, S. Sriboonchitta, C. Chaiboonsri, IJMS, 4, 54-65, (2012).

16. R.B. Barsky \& L. Kilian. Oil and the Macroeconomy since the 1970s. Journal of Economic Perspectives, 18 (4), 115-134 (2004)

17. A. A. A. Hameed, F. M. Arshad, IBBC, Sabah, (December, 2008).

18. R. Abdullah, M. B. Wahid, World palm oil supply, demand, price and prospects: Focus on Malaysian and Indonesian palm oil industry, (2010).

19. V. Rungreunganun, S. Talabkaw, S. Cherdchoo-ngarm, A Mechanism to Analyze the Price of Palm Oil, (2015).

20.R.F. Engle \& C.W. Granger, Co-integration and error correction: representation, estimation, and testing. Econometrica: journal of the Econometric Society, 251-276 (1987)

21. D.L. Hoffman \& R.H. Rasche, Assessing forecast performance in a cointegrated system. Journal of Applied Econometrics, 11(5), 495-517 (1996)

22. S. Johansen, Statistical analysis of cointegration vectors, Journal of economic dynamics and control, 12(2-3), 231-254 (1988)

23. S. Johansen, K. Juselius, Oxf. Bull. Econ. Stat, 52, 169-210, (1990).

24. C.J Granger, Developments in the study of cointegrated economic variables, Oxford Bulletin of economics and statistics, 48(3), 213-228 (1986)

25. J. L. Campiche, H. L. Bryant, J. W. Richardson, J. L. Outlaw, AAEA Annual Meeting, Portland, (July-August, 2007). 